\title{
Goussia trichogasteri n. sp. (Apicomplexa: Eimeriidae) infecting the aquarium-cultured golden gourami Trichogaster trichopterus trichopterus
}

\author{
Csaba Székely, Kálmán Molnár \\ Veterinary Medical Research Institute of the Hungarian Academy of Sciences, H-1143 Budapest, Hungária krt. 21, Hungary
}

\begin{abstract}
Goussia trichogasterin. $\mathrm{sp}$. is described from the gut of the aquarium fish Trichogaster trichopterus trichopterus. Gamogonic stages develop epicellularly in the gut epithelium. Oocysts are shed in early stage of sporulation. Sporulated oocysts are characterised by having centrally locating oocyst residua. The whole development of the species takes place in the aquarium
\end{abstract}

Few data are available on coccidian infections in aquarium fishes. Cheung et al. (1986) reported Calyptospora serrasalmi infections in Serrasalmus niger kept in aquaria; however, this infection was established before introduction of the fish to the aquarium. Coccidium-infected farm fishes, when transferred to aquaria for experimental purposes, recovered from the infection within 2 to $4 \mathrm{wk}$ and no new cycle of infection started (Musselius et al. 1963, Molnár 1976, 1979). No data have yet been published on coccidian infections of tropical ornamental fish bred and grown in aquaria

In the present paper we are reporting on a coccidian infection in Southeast Asian gourami, Trichogaster trichopterus trichopterus, grown in aquaria. Coccidia found in this fish are described as a new species: Goussia trichogasteri.

Materials and methods. The 1.5 to 2 mo old gourami originated from the stock of a pet-fish breeder in Budapest, Hungary. Forty-five fish of this stock were sent to the laboratory because of weak physical status, loss of apetite and high mortality. Contents and scrapings of the gut were studied under the light microscope at a magnification of $\times 400$. When oocysts were found, a piece of mucus containing them was placed in a small Petri dish covered with tap water. The water was changed several times during a $24 \mathrm{~h}$ incubation to promote sporulation. Traces of penicillin and streptomycin were applied to prevent bacterial growth. Oocysts which sporulated in the Petri dish were then examined in fresh preparations for morphology. Line drawings and photos were made. Tissue samples of gut segments from the infected area were fixed in Bouin's fixative, embedded in paraffin-wax, sectioned at $4 \mu \mathrm{m}$, and stained with haematoxilin and eosin (H\&E) or Giemsa stain.

To initiate an experimental infection oocysts from infected gourami were added to tanks containing parasite-free golden gourami. These fish were examined for the presence of coccidian developmental stages and oocysts in the gut at 3 to $4 \mathrm{~d}$ intervals for $3 \mathrm{wk}$.

Characteristics of the oocysts were established based on morphology and measurements of 50 oocysts. All measurements are given as mean and range.

Results. Pathological investigation of the sick gourami revealed extreme pathology in the gut. The lumen of the intestine was empty or with only scarce contents and the whole intestine was dilated. The reddened and swollen mucosa of the gut was covered by a copious, transparent mucus which contained great numbers of coccidium oocysts in various states of sporulation. Unsporulated and semisporulated oocysts were also found in mucosal scrapings. Besides coccidia, specimens of Spironucleus elegans (Flagellata) were frequently found in the gut. In $20^{\circ} \mathrm{C}$ tap water unsporulated oocysts completed sporulation within $24 \mathrm{~h}$. No coccidian infection was found after experimental infection of fish with oocysts.

Goussia trichogasteri n. sp. (Fig. 1).

Type host: Trichogaster trichopterus trichopterus.

Locality: Aquarium fish, Hungary.

Site of infection: Epithelial cells of the foregut.

Young, unsporulated oocysts (Fig. 2) are ellipsoidal, $10 \times 15 \mu \mathrm{m}(9-11.5 \times 14-16)$. They each incorporate $\mathrm{a}$ finely granulated sporont of $13.5 \times 8.5 \mu \mathrm{m}\{13-14 \times$ 8-9). More developed oocysts have a spherical or short 


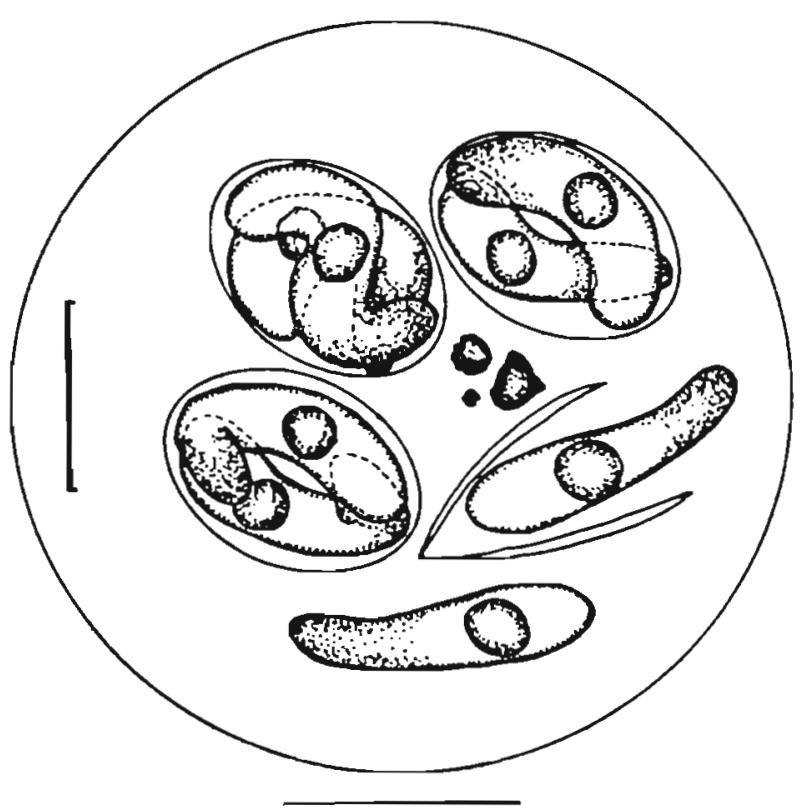

Fig. 1. Goussia trichogasteri n. sp. Line drawing of sporulated oocysts. Scale bar. $5 \mu \mathrm{m}$

ellipsoidal shape with an average size of 13 to $15 \mu \mathrm{m}$. In the latter oocysts the sporont is round, ca $9 \mu \mathrm{m}$ in diameter, and has a large space between the oocyst wall and the sporont. The sporont forms 4 sporoblasts and 3 or 2 compact sporocyst residua resembling polar granula but centrally positioned in the oocyst.

Sporulated oocysts (Fig. 2a) are spherical, and $18.3 \mu \mathrm{m}(14-24)$ in diameter. The cyst wall is thin, smooth, and transparent. Four sporocysts and 2 or 3 compact, amorphous oocyst residual bodies fill the oocyst loosely, with a wide space between the sporocysts and oocyst wall.

Sporocysts are elliptical, $5.7 \mu \mathrm{m}(4.7-6.7)$ in length and $4.2 \mu \mathrm{m}(4.0-4.9)$ in width. The sporocyst wall is thin and transparent. Each sporocyst contains 2 vermiform sporozoites with one end sometimes reflexed and arranged head to tail. A residual body is absent. The wall of the sporocyst is composed of 2 equal halves connected by a suture along the longitudinal axis Sporozoites are often freed into the oocyst lumen after the suture of the sporocyst shell opens. Free, bananashape sporozoites are $7.1 \mu \mathrm{m}(5.5-8.3)$ in length and $1.8 \mu \mathrm{m}(1.6-2.4)$ in width. The apical part of the sporozoite is of darker color with the nucleus located close to the blunt end.

In histological preparations, macrogamonts and trophozoites were located epicellularly in the epithelial cells, covered only by a smooth layer of cell membrane (Fig. 3). Most of them were found at the bottom of the mucosal folds of the mid-gut. In diseased fish the dominant sign of disease was inflammation of the gut.

Discussion. No coccidian infection of anabantid fishes has previously been recorded. Coccidia morphologically similar to Goussia trichogasteri have been found only in systematically distant fishes. Most of the known Goussia species in other fishes are characterized by sporocysts completely filling the space of the oocyst. Only a few coccidia, such as $G$. clupearum, $G$. lomi and the Goussia sp. described by Molnár \& Rohde (1988), have sporocysts filling the oocysts loosely. Of these, $G$. clupearum inhabits the liver of clupeid fishes

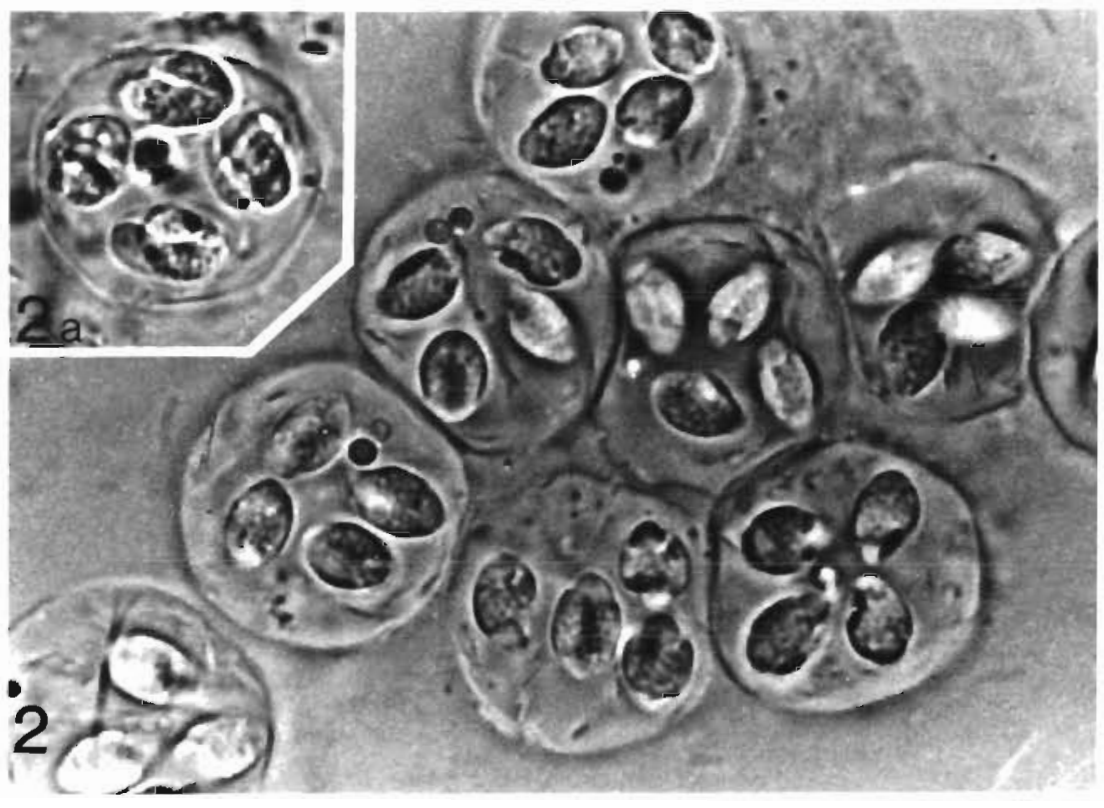

Fig. 2. Goussia trichogasteri. Semisporulated oocysts. $\times 1500$. (2a). Sporulated oocyst. $\times 1500$ 
Fig. 3. Goussia trichogasteri. Epicellularly located developing oocysts in the midgut of Trichogaster trichopterus trichopterus. H\&E-stained histological section.

$$
\times 250
$$

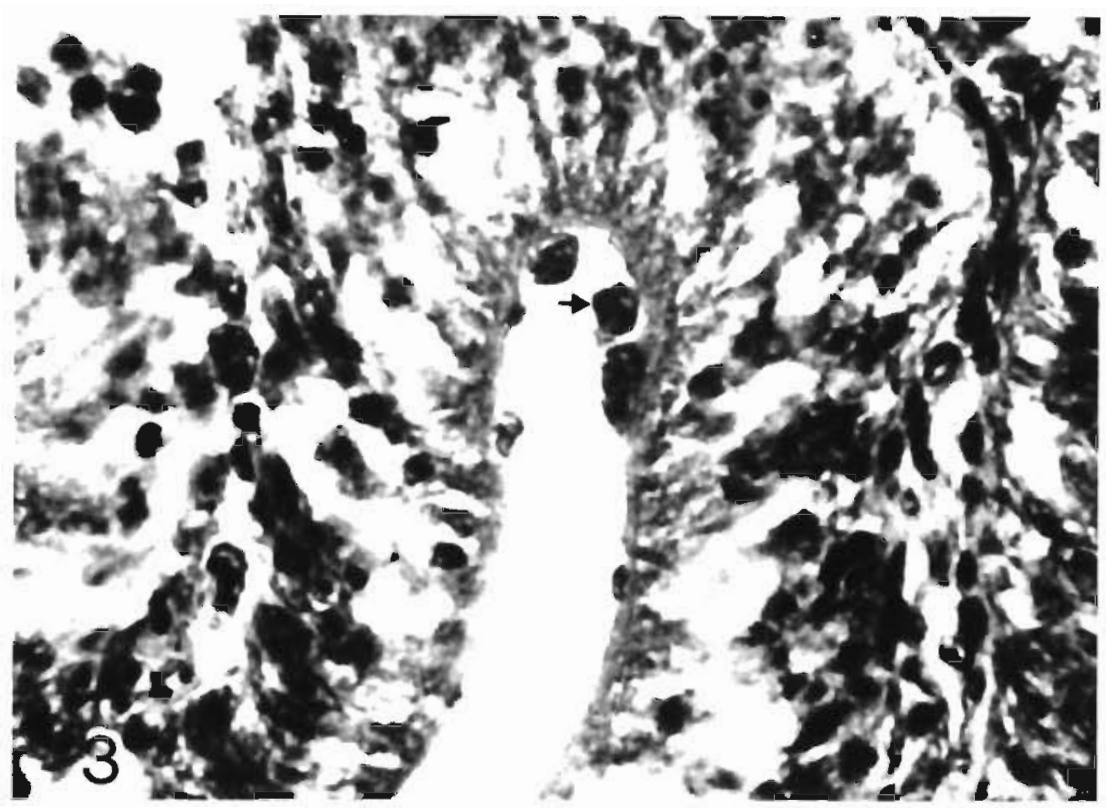

and its sporocysts are much larger than those of $G$. trichogasteri. G. lomi differs from $G$, trichogasteri by having a large oocyst residuum while the Goussia sp. (Molnár \& Rohde 1988) which most resembles $G$. trichogasteri has ellipsoidal oocysts and no oocyst residua.

Coccidian infection of fish species bred in aquaria has long been expected to occur. The only recorded infections of any aquarium-cultured fish were of the goldfish (Hoffman 1965, Romero-Rodriguez 1978, Kent \& Hedrick 1985). Aquarium-cultured goldfish can become infected through vector food organisms, which may transmit coccidia from goldfish Carassius auratus auratus cultured in ponds and from gibel carp Carassius auratus gibelio living in natural waters. Infection in this way by Goussia carpelli has been observed in goldfish by Kent \& Hedrick (1985) and Székely unpubl.).

Absence of coccidioses in aquarium fishes could be explained by the need for vectors. However, experiments by Paterson \& Desser (1982), Landsberg \& Paperna (1985) and Steinhagen \& Körting (1988) indicated that coccidian infection can also occur through feeding on oocysts. In our case the above-mentioned way of infection seems to be probable, producing a coccidian infection that developed in the aquarium without any possible contact through vector organisms with hosts in outdoor water.

It is suspected that the fish did not die from the coccidian infection alone. Other parasites, like Spironucleus, and bacteria may have contributed to the pathological process.

Responsible Subject Editor: W. Körting, Hannover, Germany

\section{LITERATURE CITED}

Cheung, P. J., Nigrelli, R. F., Ruggieri, D. (1986). Calyptospora serrasalmi sp. nov. (Coccidia: Calyptosporidae) from liver of the black piranha, Serrasalmus niger Schomburgk. J. Aquaricult. Aquat. Sci. 4: 54-57

Hoffman, G. L. (1965). Eimeria aurati n. sp. (Protozoa: Eimeriidae) from goldfish (Carassius auratus) in North America. J. Protozool. 12: 273-275

Kent, M. L., Hedrick, R. P. (1985). The biology and associated pathology of Goussia carpelli (Léger and Stankovitch) in goldfish Carassius auratus (Linnaeus). Fish Pathol. 20: $485-494$

Landsberg, J. H., Paperna, I. (1985). Goussia cichlidarumn. sp. (Barrouxiidae, Apicomplexa), a coccidian parasite in the swimbladder of cichlid fish. Z. Parasitenkd. 71: 199-212

Molnár, K. (1976). Histological study of coccidiosis caused in the silver carp and the bighead by Eimeria sinensis Chen, 1956. Acta Vet. Acad. Sci. Hung. 26: 303-312

Molnár, K. (1979). Studies on coccidia of Hungarian pond fishes. Proceedings of the International Symposium 'Coccidia and further prospects of their control", Nov. 28-30. 1979, Prague, p. 179-183

Molnár, K., Rohde, K. (1988). New coccidians from freshwater fishes of Australia. J. Fish Dis. 11, 161-169

Musselius, V. A., Ivanova, I. C., Laptev, V. I. (1963). On the coccidiosis of carp. Tr. Vses. Nauchno-Issled. Inst. Prud. Rybn. Khoz. XII: 163-196 (in Russian)

Paterson, W B., Desser, S. S. (1982). The biology of two Eimeria species (Protista: Apicomplexa) in their mutual fish hosts in Ontario. Can. J. Zool. 60: 764-775

Romero-Rodriguez, J. (1978). Coccidiopatias de peces, estudio del Protozoa Eimeriidae: Eimeria carassiusaurati, n. sp. Rev. Iber. Parasitol. 38: 775-781

Steinhagen, D., Körting, W. (1988). Experimental transmission of Goussia carpelli (Leger \& Stankovitch, 1921, Protista: Apicomplexa) to common carp, Cyprinus carpio. Bull. Eur Ass. Fish Pathol. 8: 112-113

Manuscript received: January 10, 1992

Revised version accepted: March 30, 1992 